\title{
Forchlorfenuron (CPPU): A Promising Plant Growth Regulator Augments Fruit Size, Fruit Weight, Quality and Yield of Kiwifruit (Actinidia deliciosa) cv. Hayward
}

\author{
Ajay Kumar Banyal* and Sanjeev Kumar Banyal
}

Department of Fruit Science, College of Horticulture \& Forestry, Dr YSP UHF, Neri Hamirpur, H.P. 177001, India

*Corresponding author

\section{A B S T R A C T}

\section{Keywords}

Kiwifruit, Dip,

Foliar,

Forchlorfenuron, Biozyme, Petal fall

Article Info

Accepted:

15 April 2020

Available Online:

10 May 2020
An On Farm Trial (OFT) was conducted to study the effect of different plant growth regulators viz., forchlorfenuron (CPPU) and biozyme on the development of Kiwifruit cv. Hayward in the commercial orchard of Chamba District of Himachal Pradesh during the years 2013-14 and 2014-15. The experiment was conducted at place having an approximate altitude of $1200 \mathrm{~m}$ above mean sea level. Six treatments using PGR's were applied as dip and foliar application at petal fall and 15 days after petal fall stage. The different treatments viz., $\mathrm{T}_{1}$ : Untreated control; $\mathrm{T}_{2}$ : CPPU @ 5ppm (Dip Application) at petal fall; $\mathrm{T}_{3}$ : CPPU @ 5ppm (Foliar Application) at petal fall; $\mathrm{T}_{4}$ : CPPU @ 5ppm (Dip Application), 15 days after petal fall; $\mathrm{T}_{5}$ : CPPU @ 5ppm (Foliar Application), 15 days after petal fall and $\mathrm{T}_{6}$ : Biozyme @ 2ml/litre at petal fall, were applied. The data on fruit size, fruit weight, fruit firmness and yield along with quality attributes were recorded at harvest. The application of CPPU @ 5 ppm at petal fall as dipping application obtained a significantly higher average fruit yield of $54.20 \mathrm{~kg}$ per vine. Similarly, maximum average fruit size (77.75 mm length and $53.74 \mathrm{~mm}$ diameter) and fruit weight (121.99 $\mathrm{g}$ ) was recorded with dip application of CPPU@5 ppm at petal fall. However, average minimum fruit weight (47.52 g) in untreated control. The fruits treated with CPPU obtained highest TSS $\left(17.25{ }^{\circ} \mathrm{B}\right)$ and lowest fruit firmness $\left(10.06 \mathrm{~kg} / \mathrm{cm}^{2}\right)$. The probable reason for the higher fruit weight and yield may be the exogenous application of CPPU which being synthetic cytokinin has a role in faster cell division and cell elongation. The synthetic cytokinin, CPPU (N-(2-chloro-4-pyridyl)-N-phenylurea) has been reported by various worker all over the globe to increase fruit size, fruit weight and yield significantly (Biasi et al., 1991; Lawes et al., 1992).

\section{Introduction}

Kiwi fruit is among the very few recent introductions which have surpassed in popularity due to its high nutritional value and tremendous commercial potential in the sub Himalayan region of India. A native to central China, commercially growing in New Zealand, Italy, USA, Japan, Australia, France, Chile and Spain. In India, kiwi was first 
planted in the Lal Bagh Garden at Bangaluru as an ornamental tree. With extensive research and development support its commercial cultivation has been extended to the mid hills of Himachal Pradesh, Uttrakhand, Jammu and Kashmir, Sikkim, Meghalaya, Arunachal Pradesh and Nilgiri hills in India.

Fruit growers in India's Himachal Pradesh are increasingly turning to commercial kiwifruit production and away from traditional apple cultivation in bid to diversify their crops and boost return. They are looking to kiwifruit as an alternative source of revenue, as climate change disrupts traditional apple production in Himachal Pradesh. The mid-hills and valleys of Solan, Shimla, Sirmaur, Mandi, Kullu and chamba districts are ideally suited for kiwi cultivation and have a market among high-end consumers.

Kiwi (Actinidia deliciosa Chev.) cultivation in chamba district of Himachal Pradesh is in infancy stage. Production of small sized fruits becomes a major barrier for its large-scale expansion and lagging them behind in fruit industry, especially while competing with the quality produce arriving from other parts of the world. Fruit size is one of the decisive factor that contributes toward the better price and marketability of the produce. Many studies have been conducted on fruit thinning and its effect on fruit weight and yield of kiwifruit trees (Snelgar et al., 1986; Thakur and Chandel, 2004). Although hand thinning has a positive effect on fruit size, fruit number and yield (Snelgar et al.,1986) but cases have been reported in which thinning practices did not significantly affected fruit weight. Therefore, an access to a technique which can increase fruit size without affecting yield and quality produce is necessary.

The endogenous level of different plant hormones controls cell division and cell expansion of fruit growth. Plant growth regulators/hormones are the potential tools for the quality improvement in horticultural crops and are being used to improve fruit size and yield. Desired response of the plant growth regulators depends upon the dose and the time of application. CPPU, N-(2-chloro-4-pyridyl)$\mathrm{N}$-phenylurea having cytokinin-like activity is known to enhance fruit set, improve fruit size, cluster weight and quality in kiwifruit, grapes, apple, peach, peanut and sweet melons (Nickell, 1986; Iwahori et al.,1988, Biasi et al.,1991 and Costa et al., 1990) when applied in the initial stages of fruit development. Iwahori et al., (1988) observed that the application of CPPU on fruit growth, stimulating cell division rather than cell enlargement. Increase in fruit size appeared to be dependent on direct application to the fruit (Sansavini et al., 1990). Japanese researchers reported size responses in kiwifruit, whether CPPU was applied as a dip, spray, or paste. They found that dip and spray treatments increased mean fruit weights by $35-60 \%$ with a greater response at higher $(10-30 \mathrm{mg} / \mathrm{litre})$ than lower concentrations (2-5 mg/litre). In this paper we have investigated the application technology and crop management strategies for plant growth regulators use in commercial kiwifruit orchard.

\section{Materials and Methods}

Present, investigations (OFT) were carried out on 5-years-old commercial orchard of Kiwifruit cv. Hayward in Chamba district of Himachal Pradesh during the year 2013-14. On each vine, uniform canes with same number of determinate and indeterminate fruiting laterals, were selected. The experiment was conducted as randomized block design having six treatments with 5 replicates using plant growth regulators as foliar and dip application at petal fall and 15 days after petal fall stage. The different treatments tried were $\mathrm{T}_{1}$ : Untreated control; 
$\mathrm{T}_{2}$ : CPPU @ 5ppm (dip application) at petal fall; $\mathrm{T}_{3}$ : CPPU @ 5ppm (foliar application) at petal fall; $\mathrm{T}_{4}$ : CPPU @ 5ppm (dip application) at 15 days after petal fall; $\mathrm{T}_{5}$ : CPPU @ 5ppm (foliar application) at 15 days after petal fall; $\mathrm{T}_{6}$ : Biozyme @ 2ml/litre at petal fall. During fruit growth, 25 fruits per treatment per vine were assessed for different quality parameters. The observation on different parameters viz., fruit firmness, fruit size (length and diameter), average fruit weight, fruit yield, fruit grades $(>100 \mathrm{~g}, 75-$ $100 \mathrm{~g}$ and $<75 \mathrm{~g}$ ) along with quality attributes were recorded at the time of harvesting.

After harvest, total yield and yield of different grade fruits were assessed on the basis of total fruit weight of different grades (A grade > $100 \mathrm{~g}$, B grade $75-100 \mathrm{~g}$ and $\mathrm{C}$ grade $<75 \mathrm{~g}$ ). The size of the fruits was measured in terms of length and diameter with the help of Digital Vernier Calliper and fruit weight was taken on an electronic balance, TSS ( ${ }^{0}$ Brix) and sugar percentage were recorded as per standard procedures of AOAC (1990). The data recorded was statistically analysed in accordance with the method designed by Gomez and Gomez (1984).

\section{Results and Discussion}

The influence of the synthetic cytokinin forchlorfenuron (CPPU) and biozyme on kiwifruit development as dip or foliar application at petal fall or 15 days after petal fall have been studied against the untreated control.

Fruits showed an positive and immediate response to the forchlorfenuron (CPPU) treatment, as treated fruits become larger than untreated fruits within 2-3 weeks of application. Result thus obtained 2013-14 and 2014-15 were discussed here under different heads:

\section{Fruit size}

The data pertaining to the effect different plant growth regulators viz., CPPU and Biozyme on fruit size in kiwifruit are presented in Table 1. It is evident from the pooled data that all the treatments increased fruit size in terms of average fruit length and fruit diameter significantly, except control. The Maximum average fruit length (77.75 $\mathrm{mm}$ ) of kiwifruit were obtained in the fruits with in treatment $\mathrm{T}_{2}$ i.e. CPPU@ 5 ppm as dip application at petal fall, which was statistically at par with $\mathrm{T}_{3}$ treatment. However, maximum average fruit diameter $(53.74 \mathrm{~mm})$ was found in the fruits received from the treatment $\mathrm{T}_{2}$ i.e. CPPU@ 5 ppm as dip application at petal fall, which was statistically at par with $\mathrm{T}_{3}$ treatment and followed by $T_{4}$, and $T_{5}$. It is also evident form the pooled data presented in the table that average minimum fruit length $(51.80 \mathrm{~mm})$ and fruit diameter $(45.62 \mathrm{~mm})$ was found in untreated control, which were significantly lower than other treatments. The increased fruit size by the application of synthetic cytokinin (CPPU) could be due to strong growth regulation and found very effective in accelerating fruit size. Hota et al., (2017) recorded similar results in apricot by the application of Forchlorfenuron and N-Acetyl Thiazolidine 4-Carboxylic Acid. Fruit size of kiwifruit is greatly influenced by source sink relationship as reported by Boyd and Barnett (2011).

\section{Fruit weight}

It is evident from the pooled data presented in Table 1 that maximum average fruit weight (121.99 g) was recorded with $\mathrm{T}_{2}$ treatment i.e. CPPU@ 5 ppm as dip application at petal fall, which was however, statistically in proximity with fruits obtained from the treatment $\mathrm{T}_{3}$ i.e., CPPU @ 5ppm (foliar application) at petal fall, having an average fruit weight $112.20 \mathrm{~g}$. 
However, the average minimum fruit weight $(47.52 \mathrm{~g})$ was observed in the fruits obtained from the untreated control $\left(\mathrm{T}_{1}\right)$. The enhancement in fruit size seems to be related to increase in the endogenous level of cytokinin, gibberellins and auxins (Brown and Woolley, 2010), which promote greater cell division and expansion (Woolley and CruzCastillo, 2006; Antognozzi et al., 1997) and fruits act as major sinks for water and carbohydrates (Antognozzi et al., 1997). CPPU is known to exhibit strong cytokinin like activity (Takahashi et al., 1978) and to stimulate the fruit growth in kiwifruit and apple (Biasi et al., 1991, Green, 1989). Similar responses in fruit weight were observed by (Banyal et al., 2013) in apple and (Babita and Rana, 2015) applied CPPU (urea based cytokinin) as a fruit dip treatment after 10 days of petal fall in kiwifruit cv. Allison and recorded maximum average fruit weight $(105.64 \mathrm{~g})$.

\section{Fruit yield}

The data pertaining to the effect of different plant growth regulators on average fruit yield are presented in Table 2. It is obvious from the pooled data that maximum average fruit yield $\left(54.20 \mathrm{~kg}\right.$ vine $\left.{ }^{-1}\right)$ was reported in trees treated with CPPU@ 5 ppm as dip application at petal fall $\left(\mathrm{T}_{2}\right)$ followed by $41.54 \mathrm{~kg}$ per vine with $\mathrm{T}_{3}$ treatment i.e. CPPU@ 5 ppm as foliar application at petal fall. These treatments recorded significantly higher average fruit yield than untreated control which obtained a average fruit yield of 22.18 $\mathrm{kg}$ per vine.

It can also be clearly seen that the proportion of average fruit yield having fruit weight > $100 \mathrm{~g}$ was also significantly higher (37.31 kg/vine) in treatment $T_{2}$ followed by $T_{3}$ treatment. However, untreated control having more share of fruit size less than $75 \mathrm{~g}$ which obtained an average fruit yield of 14.18 $\mathrm{kg} / \mathrm{vine}$, which fetches lowest market price.
The increased yield and higher proportion of fruit weight more than $100 \mathrm{~g}$ in the present investigation, may be due to larger fruit size and weight induced by CPPU (Famiani et al., 2007). The proportion of fruit weight $>100 \mathrm{~g}$ with CPPU application was increased. CPPU may attributed its effects in promoting larger fruit growth by increased cell division as CPPU having a cytokinin like activity. Greene (1995) in apple, and Famiani et al., (1999) in kiwifruit also obtained larger and heavier fruits following cytokinin based treatments. Vasilakakis et al., (1997) found that small size fruits in kiwifruit cv. Hayward were mainly due to overloading of vines. The findings of this study are in agreement with (Pramannik et al., 2015) in Kiwiruit. They found that higher yield with dipping fruits with CPPU @ $10 \mathrm{ml}+$ pinching $1 / 5^{\text {th }}$ at petal fall at one month interval. The present results are also in line with the findings of (Chandel and Sarita, 2010) who reported that dipping of kiwifruit cv. Allison in 2.5, 5 and $10 \mathrm{ppm}$ CPPU and 10, 20 and 40 ppm Promalin solution fourteen days after full bloom resulted in significant increase in yield.

\section{Fruit firmness}

It is revealed from the perusal of pooled data presented in Table 3 that different treatments had a marked effect on the fruit firmness. In the present investigation fruits obtained from untreated control $\left(\mathrm{T}_{1}\right)$ recorded maximum fruit firmness $\left(11.19 \mathrm{~kg} / \mathrm{cm}^{2}\right)$ whereas CPPU treated fruits registered significantly lower fruit firmness, whether applied as dip or foliar. The decrease in fruit firmness by the application of CPPU might be associated with enhanced ethylene production in fruit tissue and fruit $\mathrm{Ca}$ is decreased by dilution as fruit size increases, (Suttle, 1996). These finding are confirmed with those observed by (Fathi et al., 2011) on persimmon who reported that that Sitofex (CPPU) application resulted in lower fruit firmness than the control during both the years of study. 
Table.1 Effect of different plant growth regulators on fruit size and average fruit weight of Kiwifruit

\begin{tabular}{|c|c|c|c|c|c|c|c|c|c|}
\hline \multirow[t]{3}{*}{ Treatments } & \multicolumn{6}{|c|}{ Fruit Size (mm) } & \multirow{2}{*}{\multicolumn{3}{|c|}{ Average fruit weight }} \\
\hline & \multicolumn{3}{|c|}{ Length } & \multicolumn{3}{|c|}{ Diameter } & & & \\
\hline & 2014 & 2015 & Pooled & 2014 & 2015 & Pooled & 2014 & 2015 & Pooled \\
\hline $\begin{array}{l}\mathrm{T}_{1}: \text { Untreated } \\
\text { control }\end{array}$ & 52.37 & 51.23 & 51.80 & 47.11 & 44.13 & 45.62 & 48.80 & 46.23 & 47.52 \\
\hline $\begin{array}{l}\mathrm{T}_{2}: \mathrm{CPPU} @ 5 \mathrm{ppm} \\
\text { (Dip Application) } \\
\text { at petal fall }\end{array}$ & 79.13 & 76.37 & 77.75 & 54.31 & 53.17 & 53.74 & 120.50 & 123.47 & 121.99 \\
\hline $\begin{array}{l}\mathrm{T}_{3}: \text { CPPU @ 5ppm } \\
\text { (Foliar } \\
\text { Application) at } \\
\text { petal fall }\end{array}$ & 76.71 & 73.34 & 75.03 & 53.23 & 50.19 & 51.71 & 110.90 & 113.49 & 112.20 \\
\hline $\begin{array}{l}\text { T4: CPPU@ } 9 p p m \\
\text { (Dip Application), } \\
15 \text { days after petal } \\
\text { fall }\end{array}$ & 66.32 & 67.28 & 66.80 & 51.85 & 50.75 & 51.30 & 77.40 & 74.25 & 75.83 \\
\hline $\begin{array}{l}\text { T }_{5}: \text { CPPU @ 5ppm } \\
\text { (Foliar } \\
\text { Application), } 15 \\
\text { days after petal fall }\end{array}$ & 61.51 & 60.17 & 60.84 & 52.07 & 49.33 & 50.70 & 71.60 & 70.23 & 70.92 \\
\hline $\begin{array}{l}\text { T6: Biozyme @ } \\
2 \mathrm{ml} / \text { litre at petal } \\
\text { fall }\end{array}$ & 57.42 & 55.13 & 56.28 & 49.93 & 46.23 & 48.08 & 64.40 & 60.22 & 62.31 \\
\hline $\mathrm{CD}_{0.05}$ & 4.11 & 2.86 & 3.17 & 3.16 & 3.01 & 3.23 & 11.37 & 8.53 & 10.29 \\
\hline
\end{tabular}


Table.2 Effect of different plant growth regulators on fruit yield of Kiwifruit

\begin{tabular}{|c|c|c|c|c|c|c|c|c|c|c|c|c|}
\hline \multirow[t]{3}{*}{ Treatments } & \multicolumn{12}{|c|}{ Fruit Yield (kg/vine) } \\
\hline & \multicolumn{3}{|c|}{$>100 \mathrm{~g}$} & \multicolumn{3}{|c|}{$75-100 \mathrm{~g}$} & \multicolumn{3}{|c|}{$<75 \mathrm{~g}$} & \multicolumn{3}{|c|}{ Total Yield } \\
\hline & 2014 & 2015 & Pooled & 2014 & 2015 & Pooled & 2014 & 2015 & Pooled & 2014 & 2015 & Pooled \\
\hline $\mathbf{T}_{1}:$ Untreated control & 2.92 & 3.15 & 3.04 & 4.75 & 5.17 & 4.96 & 13.23 & 15.13 & 14.18 & 20.90 & 23.45 & 22.18 \\
\hline $\begin{array}{l}\mathrm{T}_{2}: \text { CPPU @ 5ppm } \\
\text { (Dip Application) at } \\
\text { petal fall }\end{array}$ & 35.02 & 39.60 & 37.31 & 8.76 & 9.13 & 8.95 & 7.72 & 8.17 & 7.95 & 51.50 & 56.90 & 54.20 \\
\hline $\begin{array}{l}\mathrm{T}_{3}: \text { CPPU @ } 5 p p m \\
\text { (Foliar Application) } \\
\text { at petal fall }\end{array}$ & 14.32 & 15.29 & 14.81 & 11.04 & 12.15 & 11.60 & 15.54 & 14.73 & 15.14 & 40.90 & 42.17 & 41.54 \\
\hline $\begin{array}{l}\mathrm{T}_{4}: \mathrm{CPPU} @ 5 \mathrm{ppm} \\
\text { (Dip Application), } 15 \\
\text { days after petal fall }\end{array}$ & 5.84 & 5.71 & 5.78 & 6.81 & 6.30 & 6.56 & 19.79 & 23.56 & 21.68 & 32.45 & 35.57 & 34.01 \\
\hline $\begin{array}{l}\mathrm{T}_{5}: \text { CPPU @ 5ppm } \\
\text { (Foliar Application), } \\
15 \text { days after petal } \\
\text { fall }\end{array}$ & 4.13 & 6.20 & 5.17 & 5.78 & 7.57 & 6.68 & 17.60 & 15.36 & 16.48 & 27.50 & 29.13 & 28.32 \\
\hline $\begin{array}{l}\mathrm{T}_{6}: \text { Biozyme @ } \\
2 \mathrm{ml} / \text { litre at petal fall }\end{array}$ & 2.86 & 3.75 & 3.31 & 6.38 & 7.95 & 7.17 & 12.76 & 7.45 & 10.11 & 22.00 & 19.15 & 20.58 \\
\hline $\mathrm{CD}_{0.05}$ & 11.27 & 9.21 & 13.24 & 1.76 & 1.37 & 2.19 & 2.13 & 2.74 & 3.47 & 5.31 & 7.49 & 8.23 \\
\hline
\end{tabular}


Table.3 Effect of different plant growth regulators on quality parameters of Kiwifruit

\begin{tabular}{|c|c|c|c|c|c|c|c|c|c|c|c|c|}
\hline \multirow[t]{2}{*}{ Treatments } & \multicolumn{3}{|c|}{$\begin{array}{c}\text { Fruit } \\
\text { Firmness } \\
\left(\mathrm{kg} / \mathrm{cm}^{2}\right)\end{array}$} & \multicolumn{3}{|c|}{ TSS $\left({ }^{0} \mathbf{B}\right)$} & \multicolumn{3}{|c|}{ Acidity (\%) } & \multicolumn{3}{|c|}{$\begin{array}{l}\text { Total Sugar } \\
(\%)\end{array}$} \\
\hline & 2014 & 2015 & Pooled & 2014 & 2015 & Pooled & 2014 & 2015 & Pooled & 2014 & 2015 & Pooled \\
\hline $\begin{array}{l}\mathrm{T}_{1}: \text { Untreated } \\
\text { control }\end{array}$ & 10.63 & 11.75 & 11.19 & 13.40 & 12.60 & 13.00 & 0.96 & 0.93 & 0.95 & 8.12 & 7.99 & 8.06 \\
\hline $\begin{array}{l}\mathrm{T}_{2}: \mathrm{CPPU} @ 5 \mathrm{ppm} \\
\text { (Dip Application) } \\
\text { at petal fall }\end{array}$ & 10.30 & 10.57 & 10.44 & 17.60 & 16.90 & 17.25 & 0.81 & 0.82 & 0.82 & 9.71 & 9.35 & 9.53 \\
\hline $\begin{array}{l}\mathrm{T}_{3}: \mathrm{CPPU} @ 5 \mathrm{ppm} \\
\text { (Foliar Application) } \\
\text { at petal fall }\end{array}$ & 10.10 & 10.29 & 10.20 & 16.80 & 15.87 & 16.34 & 0.83 & 0.81 & 0.82 & 9.47 & 9.51 & 9.49 \\
\hline $\begin{array}{l}\mathrm{T}_{4}: \text { CPPU @ 5ppm } \\
\text { (Dip Application), } \\
15 \text { days after petal } \\
\text { fall }\end{array}$ & 10.01 & 10.11 & 10.06 & 17.20 & 16.50 & 16.85 & 0.84 & 0.83 & 0.84 & 9.63 & 9.39 & 9.51 \\
\hline $\begin{array}{l}\mathrm{T}_{5}: \text { CPPU @ 5ppm } \\
\text { (Foliar } \\
\text { Application), } 15 \\
\text { days after petal fall }\end{array}$ & 10.12 & 10.25 & 10.19 & 16.60 & 16.30 & 16.45 & 0.82 & 0.85 & 0.84 & 9.51 & 9.13 & 9.32 \\
\hline $\begin{array}{l}T_{6}: \text { Biozyme @ } \\
2 \mathrm{ml} / \text { litre at petal } \\
\text { fall }\end{array}$ & 10.08 & 10.10 & 10.09 & 14.30 & 13.50 & 13.90 & 0.83 & 0.87 & 0.85 & 9.54 & 8.93 & 9.24 \\
\hline $\mathrm{CD}_{0.05}$ & 0.80 & 0.53 & 0.59 & 0.30 & 0.24 & 0.31 & NS & NS & NS & 0.13 & 0.11 & 0.07 \\
\hline
\end{tabular}


Production of quality kiwifruits using CPPU

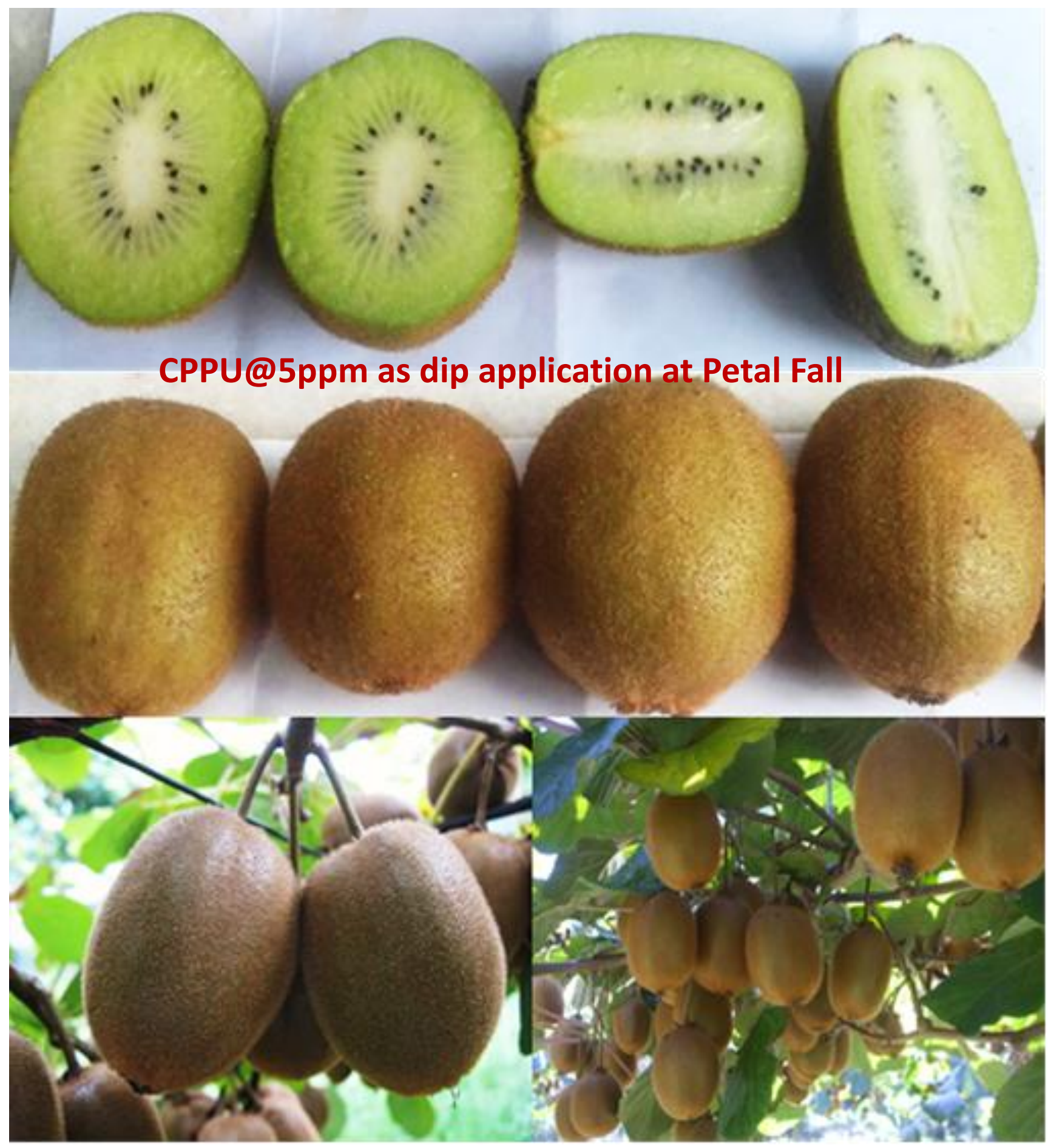




\section{Fruit quality}

It is clear from the pooled data (Table 3) that different treatments exhibited a significant influence on TSS content in fruits. The maximum TSS content $\left(17.25{ }^{\circ} \mathrm{B}\right)$ was observed in fruits acquired from trees treated with CPPU @ 5 ppm (Dip application) 15 days after petal fall, which was significantly higher that untreated control $\mathrm{T}_{1}\left(13.00{ }^{\circ} \mathrm{B}\right)$. The pooled data in Table 3 revealed that the treatment of forchlorfenuron @ 5 ppm when applied at 15 days after petal fall as dip or foliar application decreases the acid content in fruits significantly as compared to control $\left(\mathrm{T}_{1}\right)$. The maximum acidity $(0.95 \%)$ was found in fruits acquired from trees under control $\left(\mathrm{T}_{1}\right)$, while lower acidity was recorded in fruits treated CPPU and biozyme plant growth regulators. It is also revealed from the perusal of pooled data presented in Table 3 that different treatments had a marked effect on the total sugar content in fruits. The maximum average total sugars $(9.53 \%)$ was found in fruits acquired from trees treated with forchlorfenuron @ 5 ppm when applied at 15 days after petal fall $\left(\mathrm{T}_{2}\right)$, which was st par with $\mathrm{T}_{3}$ and $\mathrm{T}_{4}$ and minimum total sugars $(8.06 \%)$ was observed in the fruits from trees under control $\left(\mathrm{T}_{1}\right)$.

The results of present study are in conformity with the studies conducted by Kim et al., (2006) who reported that foliar application of Sitofix (forchlorfenuron) increased the fruit TSS content and decreased the level of acidity in kiwifruit. The higher TSS content might be attributed to a higher rate of photosynthates assimilation, as cytokinin are known to influence mobilization of metabolites and nutrients to the cytokinin treated portion of the plant (Leopold and Kriedemann, 1975). The results also in accordance with that of (Barkule et al., 2018) who observed that higher TSS content in sapota in Kallipati when treated with 6 ppm CPPU.
Hence concluded, for chlorfenuron, a phenyl urea based plant growth regulator has showed a great potential to augment the fruit size of kiwifruit both in length and diameter, when applied as a dip or foliar application. CPPU when applied @ 5ppm at petal fall (dipping application), has significantly improved fruit size, fruit weight, fruit yield along with other quality parameters. Production of bigger kiwifruits along with improved qualitative parameters will certainly boost kiwifruit production in the state and encourage farmers to compete in the market.

\section{References}

Antognozzi, E., F. Famiani and Proietti, P, 1997. Effect of CPPU treatments on fruit anatomical structure and quality of kiwifruit. Acta Horticulturae. 444: 45963.

AOAC.1980. Official methods of analysis. Association of Official Analytical Chemists. 13th ed. W. Horowitz Benjamin Franklin Station, Washington, DC: 101p.

Babita and Rana, V.S. 2015. Effect of manual fruit thinning and CPPU on the fruit yield and changes in physico-chemical composition at harvest and after storage of Allison Kiwifruit. International Journal of Bio-resource and Stress Management. 6(6):781-786

Banyal AK, R. Raina and Kaler, R.K. 2013. Improvement in fruit set, retention, weight and yield of apple cv. Royal Delicious through foliar application of plant growth regulators. J Krishi Vigyan. 2(1): 30-32.

Barkule, S.R., B.N. Patel and Baghele, R.D. 2018. Effect of 28-Homobrassinolide, CPPU, Ga3 and Humic acid on quality and shelf life of sapota (Manilkara achras) cv. Kallipatti harvested in winter. International Journal of Current Microbiology and Applied Sciences 
6:962-967.

Biasi, R., G. Costa, R.Giuliani, F. Succi and Sansavini, S.1991. Effects of CPPU on kiwifruit performance. Acta Horticulturae. 297:367-374.

Boyd, L.M. and Barnett, A.M. 2011. Manipulation of whole-vine carbon allocation using girdling, pruning, and fruit thinning affects fruit numbers and quality in kiwifruit. Hort. Science. 46: 590-595.

Brown, E. and Woolley, D. J. 2010.Timing of application and growth regulator interaction effects on fruit growth of two species of Actinidia. Acta Horticulturae. 884:107-113.

Chandel, J.S. and Sarita, D. 2010. Effect of CPPU, promalin and hydrogen cyanamide on flowering, yield and fruit quality of Kiwi fruit. Indian Journal of Horticulture. 67: 120-123.

Costa, G., T. Giuliani, S. Sansavini and Succi, F.1990. Effects of CPPU on kiwifruit morphogenesis. $23^{\text {rd }}$ IHC, Florence, Italy, Abstract of Contributed papers. 2:4251

Famiani, F., A. Battistelli, S. Moscatello, M. Boco and Antognozzi, E. 1999. Thiadiazuron effects fruit growth, ripening and quality of Actinidia deliciosa. Journal of Hort. Sci. Biotech. 74: 375-380.

Famiani, F., P. Proietti, M. Pilli, A. Battistelli and Moscatello, S. 2007. Effects of application of thidiazuron (TDZ), gibberellic acid $\left(\mathrm{GA}_{3}\right)$, and 2,4Dichlorophenoxyacetic acid (2,4-D) on fruit size and quality of Actinidia deliciosa 'Hayward'. New Zealand J Crop Horticult. Sci. 35: 341347.

Fathi, M.A., I. Azza, Mohamed and Abd ElBary, A. 2011. Effect of sitofex (CPPU ) and $\mathrm{GA}_{3}$ spray on fruit set, fruit quality, yield and monetary value of " Costata" persimmon. Nature and Science.
9(8):40-49.

Gomez, K.A. and Gomez, A.A. 1984. Statistical procedure for agricultural research $\left(2^{\text {nd }}\right.$ ed.), John Wiley, New York. pp680.

Greene, D.W. 1995. Thidiazuron effects on fruit set, fruit quality and return bloom of apples. Hort. Sci. 30: 1238-1240.

Hota, D., D.P. Sharma, S. Sharma and Singh, N. 2017. Effect of Forchlorfenuron and N-Acetyl Thiazolidine 4-Carboxylic Acid on physical parameter of apricot (Prunus armeniaca L.) cv. New Castle. Chemical Science Review and Letters. 6(24): 2408-2412.

Iwahori, S., S. Tominga and Yamasaki. T. 1988. Stimulation of growth of Kiwifruit, Actinidia Chinensis Planch., By N-(2-chloro-4-pyridyl)-N-phenyl urea, a diphenyl urea derivative cytokinin. Scientia Hort. 35:109-115.

Kim, J.G., K. Takahashi, T. Mizzugami, K. Beepu, T. Fakuda and Kata, I. 2006. CPPU application on size and quality of hardy kiwifruit. Scientia Hort.110:219222.

Leopold, A.C. and Kriedemann, P.E. 1975. Plant Growth and Development. 2nd ed. McGraw-Hill Book Company, New York.

Nickell, L.G. 1986. Effects of N-(2-chlor0--4pyridyl)-N-phenyl urea on grapes and other crops. Proceedings of the Plant Growth Regulator Society of America. 13: 236-241

Pramannik, K. K., P. Kashyap, D. K. Kishore and Sharma, Y.P.2015. Effect of summer pruning and CPPU on yield and quality of Kiwi fruit (Acnidia deliciosa). Journal of Environmental biology 36(2): 351-356.

Sansavini, S., G. Costa, S. Tartarini and Ventura, M. 1990. Effects of CPPU on apple morphogenesis. $23^{\text {rd }}$ IHC, Florence, Italy, Abstract of Contributed papers. 2:4235 
Snelgar, W.P., T.G. Thorp and Patterson, K.J.1986. Optimal leaf : fruit ratios for fruit growth in kiwifruit. Acta horticulturae. 175: 115-120.

Suttle, J.C. 1996. Cytokinin-induced ethylene biosynthesis in non-senescing cotton leaves. Plant Physiology. 82: 930-935.

Takahashi, S., K. Shudo, T. Okanoto, K. Yamada and Isoqai, Y. 1978. Cytokinin activity of N-(2-chlor0--4-pyridyl)-Nphenylurea CPPU derivatives. Phytochemistry.17:1201-1217.

Thakur, A. and Chandel, J.S. 2004. Effect of thinning on fruit yield, size and quality of kiwifruit cv. Allison. Acta Horticulturae 662:359-364.

Vasilakakis, M., K. Papazdopoulos, E. Papageorgiov, E. Sfalciotakis and Portingis, J. 1997. Factors affecting the fruit size of Hayward Kiwifruit. Acta Horticulturae. 444: 419-424.

Woolley, D. and Cruz-Castillo, J.G. 2006. Stimulation of fruit growth of green and gold kiwifruit. Acta Horticulturae.727: 291-294.

\section{How to cite this article:}

Ajay Kumar Banyal and Sanjeev Kumar Banyal. 2020. Forchlorfenuron (CPPU): A Promising Plant Growth Regulator Augments Fruit Size, Fruit Weight, Quality and Yield of Kiwifruit (Actinidia deliciosa) cv. Hayward. Int.J.Curr.Microbiol.App.Sci. 9(05): 2091-2101. doi: https://doi.org/10.20546/ijcmas.2020.905.240 